Espionage and Counterintelligence in Occupied Persia (Iran) 
Also by Adrian O'Sullivan

Nazi Secret Warfare in Occupied Persia (Iran): The Failure of the German Intelligence Services, 1939-1945 


\section{Espionage and Counterintelligence in Occupied Persia (Iran)}

The Success of the Allied Secret Services, 1941-45

Adrian O'Sullivan 


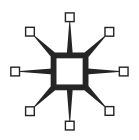

(C) Adrian O'Sullivan 2015

All rights reserved. No reproduction, copy or transmission of this publication may be made without written permission.

No portion of this publication may be reproduced, copied or transmitted save with written permission or in accordance with the provisions of the Copyright, Designs and Patents Act 1988, or under the terms of any licence permitting limited copying issued by the Copyright Licensing Agency, Saffron House, 6-10 Kirby Street, London EC1N 8TS.

Any person who does any unauthorized act in relation to this publication may be liable to criminal prosecution and civil claims for damages.

The author has asserted his right to be identified as the author of this work in accordance with the Copyright, Designs and Patents Act 1988.

First published 2015 by

PALGRAVE MACMILLAN

Palgrave Macmillan in the UK is an imprint of Macmillan Publishers Limited, registered in England, company number 785998, of Houndmills, Basingstoke, Hampshire RG21 6XS.

Palgrave Macmillan in the US is a division of St Martin's Press LLC, 175 Fifth Avenue, New York, NY 10010.

Palgrave Macmillan is the global academic imprint of the above companies and has companies and representatives throughout the world.

Palgrave ${ }^{\circledR}$ and Macmillan ${ }^{\circledR}$ are registered trademarks in the United States, the United Kingdom, Europe and other countries.

ISBN 978-1-349-55990-9

ISBN 978-1-137-55557-1 (eBook)

DOI $10.1057 / 9781137555571$

This book is printed on paper suitable for recycling and made from fully managed and sustained forest sources. Logging, pulping and manufacturing processes are expected to conform to the environmental regulations of the country of origin.

A catalogue record for this book is available from the British Library.

A catalog record for this book is available from the Library of Congress.

Typeset by MPS Limited, Chennai, India. 
For my daughter, Claire 



\section{Contents}

List of Figures viii

Preface ix

Acknowledgements xiv

Abbreviations xvii

Chronology Xxv

'Things Look Black for the Persians:

The "American Century" Begins!" xxvii

Prologue: MI5 in the Middle East 1

1 Ratcatchers 9

2 Security Threats and Operational Channels 39

3 Fifth Columnists 50

4 Fierce Tribes and Princely Playboys 64

5 Quislings and Ordinary Persians 80

6 Strategic Deceivers 95

7 Saboteurs and Spooks 101

8 Operation PONGO 120

9 Secondees from India 132

10 Interrogators and Custodians 142

11 Ruskies 153

12 'Operation LONG JUMP' 170

13 Yanks 195

14 Standing Down 231

Epilogue: The Need to Know 238

Appendix 255

$\begin{array}{ll}\text { Select Bibliography } & 260\end{array}$

Index 275 


\section{List of Figures}

1.1 PAIFORCE commander: Sir Henry Maitland 'Jumbo' Wilson 12

3.1 Sabotage target: Trans-Iranian Railway (TIR) 53

4.1 Baradaran Qashgai: Nasir Khan and his younger brothers $\quad 67$

4.2 Decorated spymaster: Gerhard Putz receives a medal from $\begin{array}{ll}\text { the Führer } & 76\end{array}$

7.1 Author and SOE propagandist: Christopher Sykes 114

8.1 Surgically removed: Fazlollah Zahedi 121

10.1 Colditz of the Middle East: Emmaus Internment Camp 151

11.1 August 1941 invasion: Red Army troops enter Tabriz 154

12.1 Notional, not national heroes: Gevork and Goar Vartanyan 185

13.1 Anglophobe extreme: Louis G. Dreyfus Jr 198

13.2 Penetrating one's Allies: Stephen 'Binks' Penrose Jr 207

A.1 Organization of DSO Persia 255

A.2 Kellar's MI5 liaison network 256

A.3 German operational channels 257

A.4 PGC Lend-Lease supply routes 258

A.5 Long-term OSS SI projects 259 


\section{Preface}

When I began drafting my first book on occupied Persia, Nazi Secret Warfare, ${ }^{1}$ I intended to write only one on the subject. However, the sheer mass of neglected material on Persia that I discovered in the British, American, and German archives soon made it apparent that my oeuvre would have to be split asunder. So here is the second half of my narrative, in which I concentrate not on the Nazis but on the activities of the Allied secret services - mainly the British - in their fight against various kinds of Axis threat which menaced the Persian polity, the Lend-Lease supply route, the oil infrastructure, and the communications links between Britain, the Indian subcontinent, Australasia, and the Far East. This story begins properly after the settling of the desert dust, stirred briefly in the late summer of 1941 by Operation COUNTENANCE, which saw several divisions of British, Indian, and Soviet soldiers crashing across the western and northern frontiers of Persia and fanning out to occupy the provinces along the Caspian coast, the major urban centres, the oilfields and refineries of Khuzistan, the Trans-Iranian Railway (TIR), and the ports on the Persian Gulf. ${ }^{2}$ From the moment that the Anglo-Soviet invasion and occupation began, these infrastructural assets instantly became potential sabotage targets of strategic significance which had to be secured and protected against Nazi-inspired attack: in the northern zone of occupation by Soviet counterintelligence and security-intelligence forces (NKVD), and in the rest of the vast hinterland by various British services, most notably MI5 (known regionally as Security Intelligence Middle East [SIME]), the Special Operations Executive (SOE), and the Field Security Sections of the Intelligence Corps (FSS).

After what Germans call die Wende (the turning point) - in other words, after they had fought and lost the fierce, crucial battles of El Alamein, Stalingrad, and Kursk - there occurred in the twilit world of political intelligence and counterintelligence what we would today term a 'paradigm shift'. From 1943 onwards, British and American intelligence priorities veered from the covert activities of the Nazis, whose ultimate military defeat was now assured, towards the political manoeuvres and manipulations of the Stalinist Russians in the Transcaucasian and Black Sea region, as they repositioned themselves in such a way as to maximize their postwar power and influence over the lands bordering the soft 
southern underbelly of the Soviet Union, to extend their hegemony to the shores of the Persian Gulf, and to exercise maximum control over the world supply of oil.

On the face of things, the convenient Stalinist proxy in Persia was the Tudeh Party, whose existence absolved the Soviets of the need to construct and remotely control a large propaganda apparatus to influence Persian political opinion. However, such a transparent entity could be monitored equally conveniently by the diplomats of the British and American legations, largely relieving the security forces of any need to surveil communist activities in Persia at the party and Majlis level. Nevertheless, as I discovered during my archival research, the British Secret Intelligence Service (MI6) and the US Office of Strategic Services (OSS), independently of each other, saw fit to insert active-intelligence operatives into the region, mainly to monitor Soviet activities within the sealed northern occupation zone, despite the fact that a moratorium existed, mutually agreed by the occupying powers, which expressly prohibited active-intelligence activities anywhere in Persia for the duration of the war.

However, the focus of this book is not on active intelligence but on security intelligence. Here the emphasis remained firmly on the Nazi menace and the task of identifying, surveilling, pursuing, and neutralizing German or pro-German elements within the Persia and Iraq Force (PAIFORCE) theatre, including saboteurs and political subversives. This was the extensive remit of the British security forces: SIME's Combined Intelligence Centre Iraq and Persia (CICI) and its Tehran branch, the Defence Security Office Persia (DSO Persia). For their part, the US security forces - the Counter Intelligence Corps (CIC) - bore responsibility only for the behaviour of their personnel operating the Lend-Lease supply route and for railway operations, not for the security of the route itself, though they routinely dealt with cases of small sabotage against railway equipment and infrastructure, as well as the frequent pilfering of materiel by the local population.

As this book reveals, Joe Spencer and the officers of DSO Persia faced a daunting task. With a staff of 20-25 people, supported by eight area liaison officers in the outposts, they policed a country 6.71 times the size of the United Kingdom. Here they maintained such routine security controls as postal and press censorship, travel and visa control, and positive vetting. At the same time they were responsible for active surveillance, prisoner interrogations, the Sultanabad (Arak) internment camp, interservice and external liaison, regular security summaries, and the establishment and maintenance of a large central registry. One 
disputed remit was responsibility for political counterespionage, which overlapped with the conventional jurisdiction of MI6, thinly disguised as the Inter-Services Liaison Department (ISLD). As the war progressed, however, a comfortable informal compromise evolved without the need for intervention from London: ISLD watched the Russians, whilst DSO Persia watched the Persians and fugitive Germans. ${ }^{3}$ Fortunately, DSO Persia were able to delegate some routine operational responsibilities to the Intelligence Corps FSS and even to the Free Polish, whose soldiers they came to regard highly as dependable prisoner escorts and guards. In fact, the DSO employed no fewer than eight Poles on their permanent staff as bodyguards, doorkeepers, and general 'strongarm men'. ${ }^{4}$ From the Persians, however, the DSO could expect nothing, for the Persian police and gendarmerie were utterly corrupt, demoralized, disorganized, and unreliable, despite zealous American attempts to advise and reform them, all of which failed.

Like my first book, this one is about Persia the operational theatre, not Persia the nation, and my narratives tell not of grand Persian endeavours, but merely of a few unsuccessful attempts by certain misguided Persian individuals, mostly exiles, to ally themselves with the odious Nazi cause, until such time as it suited them to switch sides or disappear into postoccupational obscurity. Of course, a few of these personalities like the malignant Fazlollah Zahedi, for instance - would succeed in projecting their political survival into the postwar era. However, resurrected and anointed arbitrarily with Machiavellian intent by the British and American secret services, Zahedi is an atypical exception to the general rule that supporting fascism ultimately benefited no one in Persia and cost some dearly. Tribal leaders like Nasir and Khosrow Khan Qashgai, for instance, changed sides late in the war and prolonged their struggle with the central regime, ultimately with that of the Islamic Republic, but they paid heavily for their 'nomadic romanticism', and few beyond their tribe remember them today. ${ }^{5}$ The Second World War is hardly a proud period of Persian political and diplomatic history, but it is a caesura that nevertheless merits closer study and analysis by Western political and diplomatic historians.

The rest of the story belongs to the intelligence historian, as most of the events of the period transpired in the secret world and were documented in records that have remained secret until quite recently. Unlike my first effort on German clandestine warfare in Persia, a field supported by limited documentation and therefore fairly easily comprehended, this book on Allied secret operations in the PAIFORCE theatre is about a significantly more fertile, more richly documented 
field. Therefore I hope that this book - based on a deeper and wider tranche of British and American records than Nazi Secret Warfare - will not only expose yet another hitherto opaque, neglected narrative of the Second World War, but will also provide ample scope and stimulus for a younger generation of intelligence historians to raid the archives more adventurously and thoroughly than I have been able to do. Like a pathfinder, I have therefore dropped some flares in Chapter 12 and in the Epilogue to mark the target for them by surveying the current state of the archives, warning of certain traps to avoid, and offering some unapologetically subjective advice about 'good' and 'bad' historiography. I wish them good hunting among the records, and I look forward to witnessing their attempts to eradicate the still gaping lacunae in the history of the region and of the time.

They will of course quickly learn that lacunae come in various shapes and sizes. In writing this book I encountered many minor ones that irritated rather than gaped, calling in places for a minimally speculative approach to the source material in order to ensure some measure of narrative unity. But there is a fundamental difference between informed speculation and conspiracy theory. Unlike other historical disciplines, the historiography of secret intelligence in all its manifestations (espionage, counterintelligence, subversion, etc.) is rendered especially challenging because it often depends upon primary sources that have been weeded, redacted, or restricted to a degree that makes the construction of a wholly verified and corroborated narrative impossible. The younger intelligence historian will then be faced with a radical dilemma: to write or not to write? Whether 'tis nobler in the mind to suffer passively the consequences of the weeder's black felt pen or take arms against a sea of deletions and blank pages by proactively supplying a moderately speculative narrative based on a combination of fragmentary evidence, educated guesswork, and commonsensical analysis. ${ }^{6}$ The latter, I would suggest, is a perfectly acceptable methodological solution, provided it is applied proportionally, judiciously, and as a conjunctive rather than substantive process. It is all about using connective tissue to assemble a body of historical events, not fabricating it from scratch, which is what revisionists and conspiracy theorists do. It is often the only way in which to glue together and publish in a coherent form those scattered bits of truth about the secret world that need to see the light of day, but for which the archival evidence is incomplete. We must simply trust the individual historian, young or old, to go about such delicate surgery in a skilled, enlightened manner. In fact, to ensure that this process is handled ethically, the requisite skills have more to do with language 
than with history. It is essentially about marking one's speculative statements with clear transitional expressions that say to the reader, loudly: the next bit is not based entirely on verified, corroborated archival sources, but it shows what likely happened (or did not). Therefore, words and phrases like 'probably', 'possibly', 'perhaps', and 'it can be safely assumed that' or 'it is highly unlikely that' can and should be included in the historian's legitimate thesaurus. Fail to use them, boldly and consistently, and one's historiography will be timid, tentative, and very dull. Worse yet, one might even find oneself with no stories to tell and no books to publish. But obviously, intelligence history needs to be written and published; it cannot be hobbled by purists who see a conspiracy behind every imaginative stroke of the historian's pen as he or she seeks to complete a jigsaw puzzle that often has many missing pieces. In this book I have therefore tried hard to label my occasional speculative moments clearly, either in the text itself or in the endnotes, in the hope that readers will always know when a modicum of cohesive force has had to be applied to a fragmentary narrative that would otherwise have flown apart.

Adrian O'Sullivan

West Vancouver, British Columbia

July 2015

\section{Notes}

1. Adrian O'Sullivan, Nazi Secret Warfare in Occupied Persia (Iran): The Failure of the German Intelligence Services, 1939-45 (Basingstoke: Palgrave Macmillan, 2014), abbreviated throughout to NSW.

2. NSW, 25-31.

3. See Philip H.J. Davies, MI6 and the Machinery of Spying (London: Frank Cass, 2004), 128-9.

4. Cooperation with Russian Security, Supplementary Report No. 3, 30 August 1945, KV 4/225, The National Archives, Kew, Surrey (TNA).

5. Not long after returning as ilkhan (supreme leader) from exile in the United States and Germany, Khosrow was executed publicly by the new revolutionary regime in Shiraz in 1982, after he had 'confessed' to being a CIA agent. His older brother Nasir died in exile in 1993. For more about the lives of Nasir and Khosrow Khan Qashgai, see Abbas Milani, Eminent Persians: The Men and Women Who Made Modern Iran, 1941-1979, vol. 1 (Syracuse, NY: Syracuse University Press, 2008), 261-6.

6. Cf. Hamlet, 3.1 (with apologies to the bard). 


\section{Acknowledgements}

Hundreds of hours spent on research in museums, archives, and libraries both great and small have been made more congenial and productive for me than they might have been by the knowledgeable and supportive professional staff I have encountered during the past few years in Britain, Germany, Canada, and the United States. To them all, too numerous to mention, go my sincere thanks. I also appreciate the ongoing support and encouragement I have received from various colleagues and friends at home and abroad, among them most notably Julian Brooks (Simon Fraser), Bernd Lemke (ZMSBw Potsdam), Katrin Paehler (Illinois State), and André Gerolymatos (Simon Fraser), who originally suggested that I turn my attention to Persia. A permanent expression of gratitude is owed to my former doctoral supervisors in South Africa, Tilman Dedering (UNISA) and Ian van der Waag (Stellenbosch), without whose benign patronage and constructive advice neither of my two books would have seen the light of day. When one writes in retirement, without even emeritus or adjunct status at any academic institution to bolster one's confidence, historiography can become a lonely endeavour, unless one has recourse to such a rich vein of scholarly wisdom.

As a non-affiliated historian with limited personal funds, I also greatly appreciate the kindness of those representatives of for-profit entities and other institutions who have supplied photographic materials and miscellaneous documents without charge or for a negligible sum. Thanks therefore go to Ralph Gibson (RIA Novosti) for permission to publish a rare image of two obscure KGB operatives; to Tom Neiman (Stock Montage) for permission to use an image of the US minister to Persia, Louis G. Dreyfus; to Douglas J. Wilson (USACE Office of History) for the clearance of images from the Donald Connolly Collection; to Samar Mikati Kaissi (AUB) for locating and clearing a fine image of Stephen Penrose, when those found in the CIA records proved to be of unacceptably poor quality; and to Timothy Engels (Brown) for facilitating the reproduction of a rare award certificate signed by Adolf Hitler. For ransacking resources on my behalf in my relentless but often fruitless quest to reconstruct the lives of personalities expunged from the historical record, who deserve a better fate, I also wish to thank Geoffrey P. Megargee (USHMM) and Jürgen Förster (Freiburg). For interesting insights into the current state of the Russian military archives, I thank Alex Statiev (Waterloo). For tracing 
the history of the Field Security Sections and providing obscure details about the special duties performed in Persia by certain serving personnel, sincere thanks go to a fellow member of the Special Operations Executive Group, Alan F. Judge (Military Intelligence Museum and Archives, Defence Intelligence and Security Centre [DISC], Chicksands). For kindly providing me with certain valuable but overlooked Middle East records, I must also thank another member of the SOE Group, Steven Kippax, whose tireless work at Kew over the years has disclosed many an elusive archival treasure. For clarifying questions of copyright and for tracking down elusive rightsholders, many thanks go to Debbie Usher (St Antony's College, Oxford). Last but on no account least, I wish to thank Gerhard L. Weinberg for personally granting me permission to quote from his definitive book on Nazi foreign policy. The snippets I have used cannot truly measure the profound influence that Professor Weinberg's illuminating, magisterial works have had on my understanding of Allied and Axis strategy.

I wish to thank the Trustees of the Imperial War Museum for allowing access to the collections held in the IWM Sound and Documents Section. I also wish to thank Malcolm Bell Macdonald and Jeffrey Maunsell for kindly granting me permission to quote from their fathers' memoirs held at the IWM. Unfortunately, however, despite every effort, it was not possible to trace the copyright holders of the unpublished private papers of D.W.A. Mure and E.N. Sheppard. Both the IWM and I would be grateful for any information which might help to trace those whose identities or addresses are not currently known. The same goes for the published works of George Lenczowski, Paul Leverkuehn, David Mure, Sir Reader Bullard, and Lord Wilson of Libya. Of course, every effort has been made to trace and acknowledge all copyright holders, but if any have been inadvertently overlooked, the publisher will be pleased to make the necessary arrangements at the first opportunity.

It was thrilling to interview Dr Francis Shelton, one of few remaining SOE veterans, now over 100 and in splendid intellectual form, about his Middle East adventures and the many colourful personalities he encountered there. In late-1930s Budapest, with war and persecution looming, Shelton abandoned a promising career in law, and ventured forth to Turkey and Persia with some young friends and his trusty cello as an itinerant night-club musician. Before being posted to SOE in Cairo and working for PWE in Bari, Shelton wrote propaganda for Ann Lambton at the Tehran legation and knew, among others, Herbert Underwood (the military attaché) and David Turkhud (who recruited him after he had begged Jumbo Wilson to let him join up). He was 
invited by Reza Shah and Queen Esmat on several occasions to play his cello at the imperial palace, not at grand gatherings but intimately, with the fearsome shah-in-shah and his consort mere inches from him. Shelton's fascinating stories of life in occupied Persia are legion, and he tells them with great eloquence, charm, and wit, bringing to life the tumultuous era of war and intrigue that this book depicts. Meeting this fine man was a pleasure and a privilege, and I thank him and his son Anthony for making our long conversation possible. ${ }^{1}$

Finally, as in my previous book on Persia, I must acknowledge Winston Churchill's characteristic common sense when he insisted, on the eve of the Anglo-Soviet invasion in 1941, on official use of the term Persia instead of Iran, to avoid 'dangerous mistakes [that] may easily occur through the similarity of Iran and Iraq'. ${ }^{2}$ Most contemporary British spoke of the country as Persia, and this usage is reflected in most of the documents that are the basis of this book.

\section{Notes}

1. While available in English at the Imperial War Museum (IWM), Dr Shelton's memoirs have only been published in Magyar: Francis Shelton, Különleges küldetésem: Ügynök cselloval a II. vilaghaborüban (Budapest: Scolar, 2010).

2. Minute M785/1, 2 August 1941, Prime Minister's printed personal minutes, CHAR 20/36/8, Churchill Archives Centre, Churchill College, Cambridge (CAC); NSW, xiv. Churchill showed similar concern about the possible confusion of Iceland with Ireland, directing that Iceland always be followed by a parenthetical upper-case ' $C$ '. See Winston S. Churchill, The Grand Alliance, vol. 3 of The Second World War (London: The Reprint Society, 1952), 356. 


\section{Abbreviations}

\begin{tabular}{|c|c|}
\hline $\mathrm{AA}$ & Auswärtiges Amt (Auslandsamt) (Berlin) \\
\hline Abw & Abwehr \\
\hline Abw I L & Abwehr I Luft [= German air force intelligence] \\
\hline Abw I M & Abwehr I Marine [= German naval intelligence] \\
\hline Abw II SO & Abwehr II Südost \\
\hline ADSO & Assistant Defence Security Officer \\
\hline 'A' Force & $\begin{array}{l}\text { = Cairo-based unit responsible for Middle East } \\
\text { strategic deception }\end{array}$ \\
\hline AFHQ & Allied Force Headquarters \\
\hline AGEA & $\begin{array}{l}\text { Arbeitsgemeinschaft ehemaliger Abwehrangehöriger } \\
\text { (Association of Former Members of the Abwehr) } \\
\text { [Abwehr veterans' organization] }\end{array}$ \\
\hline AIOC & Anglo-Iranian Oil Company \\
\hline ALO & Area Liaison Officer \\
\hline Amt VI & = RSHA Foreign Intelligence Department \\
\hline Amt VI C 3 & $=$ Kurt Schuback's desk at Amt VI \\
\hline Amt VI C 14 & $=$ Roman Gamotha's desk at Amt VI \\
\hline $\mathrm{AOC}$ & Air Officer Commanding \\
\hline AUB & American University of Beirut \\
\hline B & = counterespionage [as in MI5 B Branch] \\
\hline $\mathrm{B} 1 \mathrm{~A}, \mathrm{~B} 1 \mathrm{a}$ & $\begin{array}{l}\text { = MI5 counterespionage subsection administering } \\
\text { double agents }\end{array}$ \\
\hline $\mathrm{B} 1 \mathrm{~B}, \mathrm{~B} 1 \mathrm{~b}$ & = MI5 counterespionage analysis subsection \\
\hline BArch & Bundesarchiv [Berlin-Lichterfelde] \\
\hline BArch-MArch & Bundesarchiv-Militärarchiv [Freiburg] \\
\hline BAOR & British Army of the Rhine \\
\hline $\mathrm{BBC}$ & British Broadcasting Corporation \\
\hline $\mathrm{BDC}$ & Berlin Document Centre \\
\hline $\mathrm{BL}$ & British Library \\
\hline
\end{tabular}


BND Bundesnachrichtendienst [Federal Intelligence Service]

BOAC British Overseas Airways Corporation

BSC British Security Coordination

BSM Bronze Star Medal

BTE British Troops in Egypt

$\mathrm{C},{ }^{\prime} \mathrm{C}^{\prime}=$ Head of SIS (MI6)

CAC Churchill Archives Centre [Churchill College, Cambridge]

C\&CS see GC\&CS

CBE Commander of the Order of the British Empire

CC Creative Commons

CCS Combined Chiefs of Staff

CE counterespionage

CEV Centre d'Examination des Voyageurs [Aleppo, Syria]

CI counterintelligence [OSS]

CIA Central Intelligence Agency [USA]

CIC Counter Intelligence Corps [USA]

CICI Combined Intelligence Centre Iraq and Persia

CID Criminal Investigation Department [India]

CinC, C-in-C Commander-in-Chief

$\mathrm{CMG}$

Commander of the Order of St Michael and St George

$\mathrm{CO} \quad$ Colonial Office; commanding officer

CREST CIA Research Tool

CS countersubversion [OSS]

CSDIC Combined Services Detailed Interrogation Centre [Maadi, Egypt]

CUCTU Central United Council of Trade Unions [Persia]

DCOS Deputy Chief of Staff

DDMI Deputy Director of Military Intelligence

DDSP Deputy Director of Special Planning [SOE]

DIB Director of the Intelligence Bureau [India] 


\begin{tabular}{|c|c|}
\hline DSO & $\begin{array}{l}\text { Defence Security Office(r); Distinguished Service } \\
\text { Order }\end{array}$ \\
\hline DSP & Director of Special Planning [SOE] \\
\hline Exko & Executive Committee [Hizb-i-Melliun] \\
\hline FBI & Federal Bureau of Investigation [USA] \\
\hline FDR & Franklin Deleanor Roosevelt \\
\hline FHW & Fremde Heere West (Foreign Armies West) \\
\hline FKI & Freikorps Iran \\
\hline FO & Foreign Office \\
\hline FSB & $\begin{array}{l}\text { Federal'naya sluzhba bezopasnosti Rossiyskoy } \\
\text { Federatsii (Russian Federal Security Service) }\end{array}$ \\
\hline FSO & Field Security Officer \\
\hline FSS & Field Security Section(s) [Intelligence Corps] \\
\hline FUSAG & $\begin{array}{l}\text { First US Army Group [notional formation under } \\
\text { General Patton] }\end{array}$ \\
\hline G2, G-2 & Divisional Intelligence Staff Officer \\
\hline GC\&CS, GCCS & Government Code and Cipher School \\
\hline GENMISH & $\begin{array}{l}\text { United States Government Mission to the Persian } \\
\text { Gendarmerie }\end{array}$ \\
\hline Gestapo & $\begin{array}{l}\text { Geheime Staatspolizei (Secret State Police) [RSHA } \\
\text { Amt IV] }\end{array}$ \\
\hline GHQ & General Headquarters \\
\hline GHQ (ME) & General Headquarters Middle East \\
\hline GI & US serviceman [colloquialism] \\
\hline GMDS & $\begin{array}{l}\text { German Military Document Section [Camp } \\
\text { Ritchie, MD] }\end{array}$ \\
\hline GOC & General Officer Commanding \\
\hline GOI & Government of India \\
\hline GRU & $\begin{array}{l}\text { Glavnoye Razvedyvatel'noye Upravleniye (Russian } \\
\text { Armed Forces Main Intelligence Directorate) }\end{array}$ \\
\hline GSI, GS(I) & General Staff Intelligence \\
\hline GSI(c) & $=$ original designation for SIME \\
\hline $\mathrm{HM}$ & His (Her) Majesty('s) \\
\hline
\end{tabular}




$\begin{array}{ll}\text { HMG } & \text { His (Her) Majesty's Government } \\ \text { HMI } & \text { Hizb Mille Iran (Persian National Party) } \\ \text { HMSO } & \text { His (Her) Majesty's Stationery Office } \\ \text { HQ } & \text { headquarters } \\ \text { HUMINT } & \text { human intelligence } \\ \text { IA } & \text { Indian Army } \\ \text { IARO } & \text { Indian Army Reserve of Officers } \\ \text { IB } & \text { Intelligence Bureau [India] } \\ \text { i/c } & \text { in command of } \\ \text { IDB } & \text { illegal diamond buying } \\ \text { INA } & \text { Indian National Army } \\ \text { IO } & \text { intelligence officer; interrogating officer } \\ \text { IP } & \text { Iran Parastan [political party] } \\ \text { IPI } & \text { Indian Political Intelligence }\end{array}$

ISLD Inter-Services Liaison Department [= MI6 Middle and Far East]

ISOS Intelligence Service Oliver Strachey [= Abwehr manual ciphers]

IWG International Working Group

IWM Documents Collection, Imperial War Museum

JCS Joint Chiefs of Staff

KGB Komitet Gosudarstvennoi Bezopasnosti (Committee of State Security) [USSR]

KONO Kriegsorganisation Nahost [= Abwehr outstation in Istanbul]

LO Liaison Officer

LOM Legion of Merit

MA Military Attaché

MBE Member of the Order of the British Empire

ME Middle East

MEC Middle East Command

MECA Middle East Centre Archive [St Antony's College, Oxford] 


\begin{tabular}{|c|c|}
\hline MEF & Middle East Forces \\
\hline MEIC & Middle East Intelligence Centre \\
\hline MEW & Ministry of Economic Warfare \\
\hline MHQ & Mohammed Huseyin Qashgai \\
\hline MI5 & $\begin{array}{l}\text { Military Intelligence Dept } 5 \text { [colloquial designation } \\
\text { for the Security Service] }\end{array}$ \\
\hline MI6 & $\begin{array}{l}\text { Military Intelligence Dept } 6 \text { [colloquial designation } \\
\text { for the Secret Intelligence Service] }\end{array}$ \\
\hline MI9 & Military Intelligence Dept 9 [escape and evasion] \\
\hline MI14 & $\begin{array}{l}\text { Military Intelligence Dept } 14 \text { [surveillance of } \\
\text { Germany] }\end{array}$ \\
\hline MilAmt & Militärisches Amt (RSHA Military Department) \\
\hline Mil C & $\begin{array}{l}\text { Militärisches Amt C [= post-merger RSHA equivalent } \\
\text { of Abwehr I Ost] }\end{array}$ \\
\hline Mil D & $\begin{array}{l}\text { Militärisches Amt D [= post-merger RSHA equivalent } \\
\text { of Abwehr II] }\end{array}$ \\
\hline MilKo & Military Subcommittee [Hizb-i-Melliun] \\
\hline MMQ & Malek Mansour Qashgai \\
\hline MTS & Motor Transport Service [US Army] \\
\hline NARA & $\begin{array}{l}\text { National Archives and Records Administration } \\
\text { [USA] }\end{array}$ \\
\hline $\mathrm{NCO}$ & non-commissioned officer \\
\hline NKVD & $\begin{array}{l}\text { Narodnyi Kommissariat Vnutrennikh Del (People's } \\
\text { Commissariat for Internal Affairs) [USSR] }\end{array}$ \\
\hline NOIC & Naval Officer in Charge \\
\hline NSW & Nazi Secret Warfare in Occupied Persia (Iran) \\
\hline NUS & National Union of Students \\
\hline OBE & Officer of the Order of the British Empire \\
\hline OC & Officer Commanding \\
\hline OIC & Officer in Charge \\
\hline $\mathrm{OKH}$ & $\begin{array}{l}\text { Oberkommando des Heeres (High Command of the } \\
\text { German Army) }\end{array}$ \\
\hline OKW & $\begin{array}{l}\text { Oberkommando der Wehrmacht (High Command of } \\
\text { the German Armed Forces) }\end{array}$ \\
\hline
\end{tabular}




$\begin{array}{ll}\text { OPD } & \text { Operations Division [US War Department] } \\ \text { OR } & \text { other ranks } \\ \text { OSS } & \text { Office of Strategic Services [USA] } \\ \text { OTI } & \text { Office of Technical Information [USA] } \\ \text { PAIC } & \text { Persian and Iraq Command } \\ \text { PAIFORCE } & \text { Persia and Iraq Force } \\ \text { PD } & \text { public domain } \\ \text { PGC } & \text { Persian Gulf Command (December 1943 onwards) } \\ \text { PGSC } & \text { [USA] } \\ \text { PIAW } & \text { Persian Gulf Service Command (up to December } \\ \text { PICME } & \text { 1943) [USA] } \\ \text { PoKo } & \text { Preventive Intelligence Arab World } \\ \text { POLINT } & \text { Political Intelligence Centre Middle East } \\ \text { POW } & \text { Political Subcommittee [Hizb-i-Melliun] } \\ \text { PWE } & \text { Political intelligence } \\ & \text { prisoner(s) of war } \\ \text { RAF } & \text { Political Warfare Executive [created in 1941 from the } \\ \text { RAMC } & \text { SOE propaganda department (SO1)] } \\ \text { RfA } & \text { Royal Air Force } \\ \text { RGVA } & \text { Royal Army Medical Corps } \\ \text { RIA } & \text { Reichsstelle für (den) Aussenhandel (Reich Office of } \\ \text { RNOH } & \text { Foreign Trade) } \\ \text { RNVR } & \text { Russian State Military Archive } \\ \text { RSHA } & \text { Russian Information Agency } \\ \text { SAS } & \text { Royal National Orthopaedic Hospital } \\ \text { SBS } & \text { Royal Naval Volunteer Reserve } \\ \text { SD } & \text { Reichssicherheitshauptamt (Reich Security } \\ \text { SHAEF } & \text { Administration) } \\ \text { SI } & \text { Special Air Service } \\ \text { Special Boat Service } \\ \text { Sicherheitsdienst (SS Security Service) } \\ \text { Supreme Headquarters Allied Expeditionary Force } \\ \text { PAligence [OSS] }\end{array}$


SIFE

SIGINT

SIME

SIS

SK

SKL

SMERSH

SNOPG

SO1

SOAS

SOE

SS

SSE

SVR

TAP

TASS

TIR

TJFF

TNA

UCL

UK

UKCC

UNISA

USACE

USAFIME
Security Intelligence Far East

signals intelligence

Security Intelligence Middle East [= MI5, Cairo]

Secret Intelligence Service (MI6)

Sonderkommando (special squad) [in the SS this was a euphemism for extermination squad, but not of course in the German army (for example, SK Bajadere)]

Seekriegsleitung (Maritime Warfare Command)

[German supreme naval HQ]

Smert' Shpionam (Death to Spies) [Red Army counterintelligence] [USSR]

Senior Naval Officer Persian Gulf

= SOE propaganda department which became PWE in 1941

School of Oriental and African Studies [University of London]

Special Operations Executive

Schutzstaffel [Nazi Party security forces]

special source exploitation

Sluzhba vneshney razvedki (Russian Foreign

Intelligence Service)

Truck Assembly Plant [US Army]

Telegrafnoye Agentstvo Sovetskogo Soyuza (Telegraph Agency of the Soviet Union)

Trans-Iranian Railway

Transjordan Frontier Force

The National Archives [UK]

University College London (University of London)

United Kingdom

United Kingdom Control Commission

University of South Africa

United States Army Corps of Engineers

United States Army Forces in the Middle East 
xxiv Abbreviations

USGPO United States Government Printing Office

USHMM United States Holocaust Memorial Museum

USS

United States Ship

WCNA Whitman College and Northwest Archives

WD War Department

WDGS War Department General Staff

WDSS War Department Special Staff

WE war establishment

WO warrant officer

WO2 Warrant Officer Class 2 (Company Sergeant-Major or equivalent)

W/T wireless telegrapher/telegraphy [= radio operator/ radio]

$\mathrm{X}-2 \quad$ counterespionage [OSS] 


\section{Chronology}

8 Nov 1940 Mayr and Gamotha arrive in Pahlavi under commercial cover.

19 May 1941 Schulze-Holthus arrives in Tabriz under diplomatic cover.

30 May 1941 Rashid Ali Gailani flees to Persia from Iraq.

Jun-Jul 1941 SIME establishes CICI in Baghdad.

25 Aug 1941 Operation COUNTENANCE: British and Soviet troops occupy Persia.

Jan 1942 CICI remit extended to include Persia; Spencer posted to Tehran as DSO.

29 Jan 1942 Anglo-Soviet-Persian Treaty of Alliance signed.

23 April 1942 Japanese legation in Tehran closed; Japanese diplomats expelled.

22 Jun 1942 Schulze-Holthus joins Nasir Khan in Qashgai territory

Jul 1942 Mayr and Vaziri organize Hizb-i-Melliun.

August 1942 PGSC established; CIC deployed.

3 August 1942 Harris-Griffiths murder in Lorestan.

2 Nov 1942 Mayr's house in Isfahan raided and key documents seized.

Nov 1942 Wilson, Bullard, Maunsell, and Wood plan operations against Melliun.

9 Nov 1942 Schulze-Holthus's Farrashband landing ground discovered.

8 Dec 1942 Operation PONGO: Zahedi arrested and interned.

14 Jan 1943 Force Kalpak expedition sent to southern Persia.

22 Mar 1943 FRANZ expedition dropped at Siah Kuh.

May 1943 Persian troops occupy parts of Qashgai territory.

15 May 1943 Penrose posted to Cairo as head of OSS SI.

28 Jun 1943 DORA group sent by Mayr to Bakhtiari territory. 
17 July 1943 ANTON expedition dropped near Shiraz.

2 Aug 1943 Schulze-Holthus joins the ANTON group.

11 Aug 1943 Spencer releases his fifth-column master plan.

15 Aug 1943 Spencer arrests Mayr at gunpoint.

29 Aug 1943 The entire FRANZ group is now in custody.

9 Sep 1943 Persia ends its neutrality and declares war on Germany.

23 Sep 1943 Schulze-Holthus and the ANTON group transferred to Boir Ahmedi custody.

28 Nov 1943 Churchill, Roosevelt, and Stalin meet in Tehran.

Jan 1944 Crawford succeeds Penrose as head of OSS SI.

1 Mar 1944 Schulze-Holthus and the ANTON group returned to the Qashgai by the Boir Ahmedi.

21 Mar 1944 Dreyfus transferred to Iceland.

22 Mar 1944 KISS establishes contact with MARQUIS.

23 Mar 1944 Schulze-Holthus and the ANTON group surrendered by the Qashgai.

31 Mar 1944 Qashgai Brothers return to Persia from 12-year exile.

Apr 1944 Kellar first visits DSO Persia.

Aug 1944

OSS inserts two active-intelligence agents into the Soviet zone.

17 Jan 1945 Schulze-Holthus repatriated to Germany in exchange for British agent.

2 Apr 1945 Last German agent (Jakob) captured on Persian soil.

3 May 1945 MARQUIS transmits final farewell message to KISS.

Dec 1945 Last US forces leave Persia.

Feb 1946 Last British forces (73 FSS) leave Persia.

Apr 1946 Last Soviet forces leave Persia. 


\section{'Things Look Black for the Persians: The "American Century” Begins!"}

\section{Die Iraner sehen schwarz -}

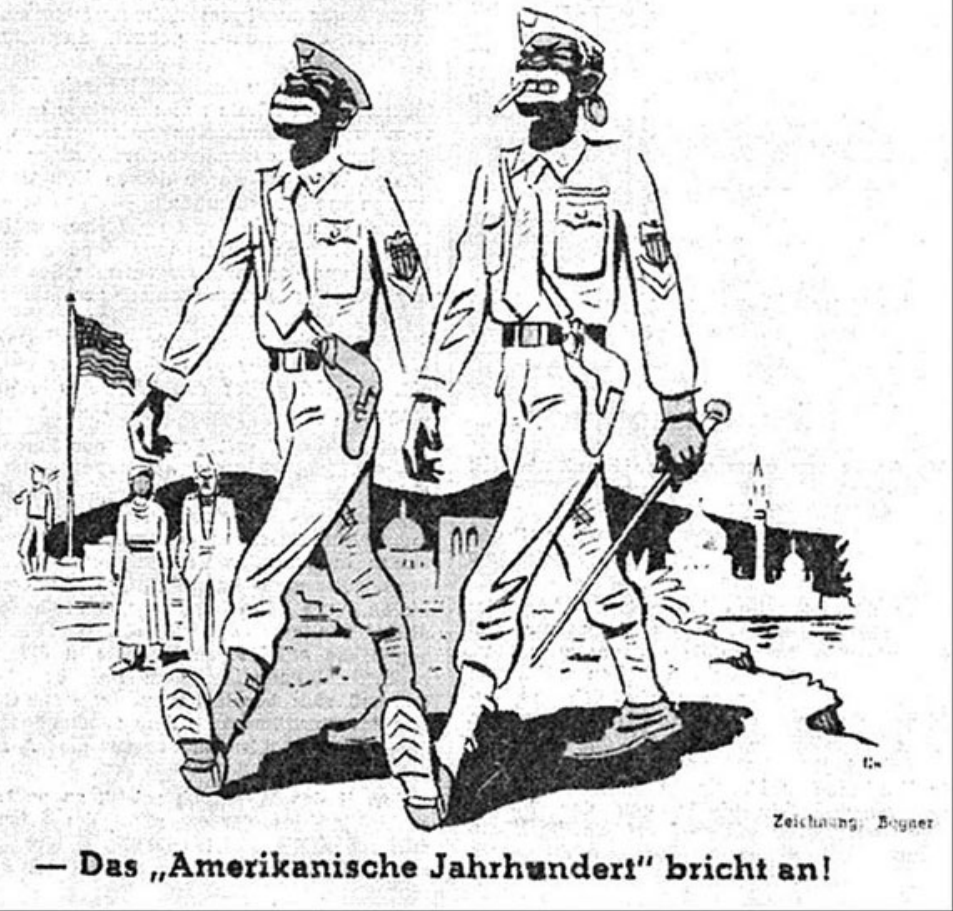

Anti-American racist cartoon in the official SS newspaper, Das Schwarze Korps (12 November 1942)

Under overall Sicherheitsdienst (SS Security Service [SD]) editorial control, with the rabidly antisemitic Günther d'Alquen of the Waffen-SS as editor-in-chief, this weekly propaganda broadsheet featured articles laden with race hatred, some of which proudly proclaimed the splendid work of SS Death's Head units in the Nazi concentration camps. The paper's wide popularity, with a circulation in the hundreds of thousands, makes a nonsense of claims by ordinary Germans that they knew nothing of the camps. 
When this cartoon appeared, a couple of months before their staggering rout at Stalingrad, the Germans still planned to occupy Persia themselves. Despite the lip-service paid cynically by Nazi ideologues like d'Alquen to pure Persian 'Aryanism', which explains the smug condescension displayed here towards the blackface American occupiers, things would no doubt have looked far 'blacker' for the racially tolerant Persians, had they been forced to host a permanent army of arrogant, bigoted, 'Aryan' SS-men for a millenium, instead of about 4000 African-American Gls - mostly egalitarian, easy-going, hard-working truck drivers, train drivers, and clerks - for a mere couple of years. 